\title{
Immunoparalysis in critical ill patients and its association to nosocomial and opportunist infections. a preliminary study
}

\author{
E Villarreal, P Ramirez, L Cordon, P Geffner*, A Cortes, M Gordon, E Gonzalez, P Kot, J Ruis, A Sampere \\ From ESICM LIVES 2015 \\ Berlin, Germany. 3-7 October 2015
}

\begin{abstract}
Introduction
There is a growing molecular and clinical evidence of immune impairment or immunoparalysis (IP)in critically ill patients.IP could be a physiological attempt to return to homeostasis after an intense pro-inflammatory phase and would explain the prevalence of nosocomial and opportunist infections, in critically ill patients initially considered as an immunocompetent patients.
\end{abstract}

\section{Objectives}

1. Evaluate the immune status of immunocompetent critically ill patients at admission, and on day 3 and 7.

2. Analyze the relationship between the immune status of the critically ill patient and the risk of nosocomial or oportunist infections.

\section{Methods}

Prospective and observational study.We included patients older than 18 years old, admitted to ICU and undergoing mechanical ventilation, who have been presented an acute failure of unless two organs.

At admission, and on day 3 and 7, we determined:

-Immunophenotypic lymphocyte subpopulations (ILS) ( $\mathrm{T}, \mathrm{B}$ and $\mathrm{NK}$ ), concentration of immunoglobulins in serum, and expression of HLA-DR on monocytes and FOXP3 on T cells.

- Mini-bronchoalveolar lavage for bacterial, viral and fungal culture, detection by polymerase chain reaction of cytomegalovirus, herpes simplex virus and Aspergillus spp, and determination of galactoman.

- Serum sample to detect immunoglobulins (IgM and IgG) against HSV and CMV, and quantitative measurement of CMV DNA.In those patients diagnosed and

Hospital La Fe, Valencia, Spain

C 2015 Villarreal et al.; This is an Open Access article distributed under the terms of the Creative Commons Attribution License (http:// creativecommons.org/licenses/by/4.0), which permits unrestricted use, distribution, and reproduction in any medium, provided the

original work is properly cited. treated for nosocomial or opportunist infection, we evaluated the same variables, the day of infection and after $72 \mathrm{~h}$.

All results are expressed as the median with interquiartile. Statistical analysis was performed using the Mann-Withney U test or kruskall-Wallis analysis. Data will be processed with SPSS 16.0.

\section{Results}

23 patients were included.The study population contained $77,3 \%$ male, with a median age of 59 years. Baseline severity of illness was quantified using the SAPSIII score, the median was 63 . The main reason for admission was cerebrovascular accident $31,8 \%$ and sepsis $(13,6 \%)$. Mortality rate was $59 \%$.At admission, levels of different ILS, concentration of immunoglobulins in serum and expression of HLADR were lower than those found in subsequent tests, without statistically significant differences. Six patients were diagnosed of a nosocomial infection (83\% ventilator associated pneumonia) and one was diagnosed of an oportunist infection (invasive pulmonary aspergillosis).

The deceased patients with a nosocomial infection, when they were diagnosed, had lower levels of ILS immunoglobulins, and expression of HLADR and FOXP3 than survivors, without statistically significant differences (table 1).

\section{Conclusions}

At admission in intensive care unit there was an immunosuppression.Patients with nosocomial and opportunist infection, show a lack of immune recovery at the immune monitoring. This immunosuppression is more marked in deceased patients and therefore could be correlated with an increase of mortality. \\ SpringerOpen ${ }^{\circ}$}


Table 1. Patients with nosocomial infection

\begin{tabular}{lll}
\hline & Survivors & Deceased \\
\hline CD3 & $1237[185-1243]$ & $911,5[740-1083]$ \\
\hline CD8 & $446[52-689]$ & $376,5[279-454]$ \\
\hline NK & $279[58-663]$ & $42[20-64]$ \\
\hline $\operatorname{lgA}$ & $84[15-132]$ & $63[54-72]$ \\
\hline $\operatorname{lgG}$ & $353[133-450]$ & $226[160-293]$ \\
\hline IgM & $1080[973-1660]$ & $671[660-683]$ \\
\hline TregsFoxP3+ (\% T cell) & $44,5[39,9-49,12]$ & $29,4[4,96-38,8]$ \\
\hline HLADR+ (\% PMN) & $52,8[50,6-55]$ & $40,03[27,04-85,33]$ \\
\hline
\end{tabular}

Published: 1 October 2015

doi:10.1186/2197-425X-3-S1-A1016

Cite this article as: Villarreal et al:: Immunoparalysis in critical ill patients and its association to nosocomial and opportunist infections. a preliminary study. Intensive Care Medicine Experimental 2015 3(Suppl 1): A1016.

\section{Submit your manuscript to a SpringerOpen ${ }^{\oplus}$} journal and benefit from:

- Convenient online submission

- Rigorous peer review

- Immediate publication on acceptance

- Open access: articles freely available online

- High visibility within the field

- Retaining the copyright to your article 